\title{
Developing Geography Learning Model to Strengthen Student Character
}

\author{
Budi Handoyo, Purwanto \\ Department of Geography \\ Universitas Negeri Malang \\ Malang, Indonesia \\ budi.handoyo.fis@um.ac.id
}

\begin{abstract}
Reflecting the people development at the last decade showed that there was a more and more decay of the people moral. The cases of corruption, violence, pornography up to mass cheat on the exam have contaminated the young generation as well as children. The realities raise the new awareness to strengthen the character education through learning improvement. The objective of this research was to develop a geography learning model for strengthening student character. This research was a development research by using modified Borg and Gall who has eight steps, namely, need analysis, planning, developing a preliminary form of product, preliminary field testing, revision of main product, playing field testing, revision of the product, and the final revision of the product. The data were collected by questionnaire and interview. The interview was deeply conducted to get comprehensive information over the learning syntax. The research subjects were the students of SMA 10 Malang. The research result is called geography learning model to strengthen student character (GLSC). There are eight steps of the model: orientation of geographical phenomena, identifying and formulating problems, doing fieldwork, organizing, analyzing, and concluding the results of data analysis, developing and selecting solutions, taking action, composing reports and communication, and reflection. The validation scores were higher than the predefined criteria scores, $87,5 \%>76 \%$. The resulted score of the tryout was also higher than the criteria score, $87,75 \%>76 \%$. Based on the result, the Geography Learning to strengthen student character is valid to be used for the geographical learning.
\end{abstract}

\section{Keywords—geography learning, character value}

\section{INTRODUCTION}

The role of the character building has been increasingly realized since the last few years by the Indonesian government as a national education stakeholder [1], [2]. This awareness growth is because of the massive decline of social morality, especially among teenagers and children, such as violence, pornography, a mass brawl, and mass cheating.

The character is a typical way of thinking and behaving to live and work together in the family, society, nation, and state. A person can make decisions and take responsibility for the decisions he/she makes [3]. The values of human behavior relating to God, self, fellow human beings, the national environment embodied in thoughts, attitudes, feelings, words, and deeds based on religious norms, laws and rules of culture and customs [4]. Referring to the concept, there are nine pillars of the universal values of noble character, the love of God and all of His creations, independence and responsibility, honesty, diplomatic, respectfulness and politeness, generosity, being helpful and cooperative, confidence and hard workers, leadership and justice, being good and humble, tolerance, peace, and unity. Meanwhile, the Ministry of Education of Indonesia [5] elaborated 18 values of the nation character that need to be grown in schools, namely religious, honest, tolerant, discipline, hard work, creative, independent, democratic, curiosity, nationalism, achievement, friendship/communicative, peace-loving, being a reader, caring environment, social caring, and responsibility.

Effective schools have a learning system that can grow the student's character values. This connection nationally has established National Learning Process Standards applied to all teachers in planning, implementing the learning in school. The learning standards are required to refer to eight main subjects, i.e. inspiring, interactive, challenging, fun, motivating, building initiative, creative, and self-reliance [6].

Such learning quality will encourage students to understand core values by studying and discussing them, observing model behavior and practicing problem-solving. Students learn to care about core values by developing empathy skills, forming attentive relationships, helping to create a moral community, listening to illustrative and inspirational stories, and reflecting on life experiences. In such a context, dialogical learning is needed between teachers and students, students with students, and students with all school children. In classroom, cooperative learning can be applied by providing reinforcement at group activities.

The learning objectives, curriculum, and strategy must also lead to the creation of a social climate that provides opportunities for students to grow in learning. Learning needs to be organized to encourage students to learn. Learning is no longer seen as an effort to prepare the child to enter the future, but as a process in order a person could succeed in "life" anytime, anywhere, and in any situation. Thus, the performance output and learning outcomes will demonstrate broad knowledge competencies sustained by functional life skills such as faithfulness, democracy, skill, respect, social and environmental concerns, and so on. Such school graduates are not only successful in completing various school exams, but also competent in daily life within the scope of family, society, and country. 
On the other hand, ineffective learning systems can cause psychological problems. Education curriculum is too heavysuitable only for a small percentage of learners, incompetent educators in designing and implementing learning will cause problems. Most learners have difficulty adjusting to the burden of the curriculum, as well as difficulty in developing the other potentials associated with the other self-potentials. Learning systems in such schools can negatively affect the effort to build character [7]. It is because, since the early age, children had been "positioned inferior" self-confidence. The prolonged sense of inadequacy will create a person lacking of selfconfidence and creating prolonged stress. For adolescents who are unable to cope, they can experience a decline in psychological, physiological, and social conditions that cause problems for them. Uncertain confidence, anxiety, irritability and uncontrollable anger to brawl, brawl, consuming alcohol and drugs until trapped in pornography can be experienced.

Today's geography learning has not been able to fulfill the demands of these expectations. The learning tends to be content-centered, theoretical and abstract, focusing on the classroom with rigorous procedures, less media usage, and normatively judgmental. Such conditions occur due to many factors, such as the lack of geography teacher's competence in developing learning, choosing approaches and learning strategies, as well as assessing [8], [9]. Therefore, one of the strategic steps that need to be done in the future is developing a model of geography learning that can respond to the growing needs of knowledge of students and the stable character.

\section{METHOD}

This research used development research by using modified Gall [10]. It uses eight steps, namely need analysis, planning, developing the preliminary form of product, preliminary field testing, revision of the main product, playing field testing, revision of the product, and revision of the final product. The subjects of the research were the students of SMA 10 and the research validator was a doctor of geography education.

The data were collected by using questionnaire and interview. The interview was deeply conducted to get comprehensive information over the learning syntax. The activities of tryout were designed as follows: (a) a review of the learning expert to determine the accuracy of the learning steps that reinforce the learner's character. The study was conducted by two experts, one expert from geography learning, and another one from value education. (b) Field trials were used to revise the learning model before being used in the learning process.

The data analysis used a descriptive method. The data were analyzed using expert judgment. The validity test was conducted on the geography learning model for character reinforcement by expert validators in the syntax of learning models. The validator provided an assessment of the geography learning model for character engagement. All validators provided scores and suggestions on the questionnaires given to them. In addition, validators also took conclusions in the form of validity of learning models that had been produced. The results of the scores and suggestions were analyzed descriptively. The quantitative data were analyzed by percentage, and the eligibility criteria used score at least $76 \%$.

\section{RESULTS AND DISCUSSION}

The results of this research development is a model of Learning Geography Learning to Strengthen the learners' Character (GLSC) which includes eight steps, namely orientation of geographical phenomena, identifying and formulating problems, doing fieldwork, organizing, analyzing, and concluding the results of data analysis, developing and selecting solutions, taking action, composing reports and communication; and reflection.

The orientation of geographical phenomena is a way to introduce students to happening phenomena. The purpose of this step is to introduce students to the variety of phenomena that occur and the problems. These phenomena can be natural and non-natural such as floods, landslides, volcanic eruptions, drought, forest fires, urban poverty, slum dwellers, garbage, and so on. The teacher conveyed, in general, the phenomena that had occurred and were happening by raising the result. By presenting the results, the students were expected to be inspired to determine the phenomenon and what problems would be their attention to be studied further.

Identifying and formulating problems are the steps to sort out the problems of the phenomena that the students were concerned about. Every phenomenon has problems that are not singular but plural. Students should try to well recognize the problem, and choose one problem that suits their interests. Based on the selected issues the case was discussed to form the problem formulation. The problem formulation begins with the use of a question sentence.

Doing fieldwork is a step to collect the data from the field. The data was collected by measurement, observation, and or interview. This step requires preparations for the data obtained in accordance with the objectives to be achieved. Therefore, it is necessary to prepare instruments for the collection of such data.

Organizing, analyzing, and concluding the results of data analysis are the steps to process the data collected from fieldwork. The collected data were converted into tables or graphs. The data that had been input in the table were red or interpreted and written down. The data that had been organized, were then analyzed by using geographical analysis. The data could be analyzed both quantitatively and qualitatively or using a combined analysis of both. For example, it could use spatial analysis with technical analysis of interaction, synergy, or the other analytical techniques.

Developing and selecting solutions are the steps to develop alternative solutions to the problems that have been formulated. In this step, the students developed more problem-solving alternatives. The next step was choosing one of these problemsolving alternatives to be used to solve the problems that had been formulated.

Taking action is a concrete step of action to solve the problems that have been formulated. The action was taken from the solution of the selected problem. To carry out the 
action, the students must draw up an action plan and negotiate with the parties related to the plan.

Composing reports and communication is the step of preparing a report on the whole processes that have been done. The report does not need to be bold, it is important that all aspects of the learning can be reported. After completing the report, the students prepared the presentation materials. The presentation could be done by employing a presentation application or a simple technique based on available resources.

Reflection is a step to review the lessons learned from the first step to the last step. Reflection can be carried out using the question of how are our roles during learning?. The extent to which students engage in learning. Reflection questions could also be institutionalized towards what lesson could be taken for each of them.

The results of validation product development are (1) data of validation result of learning expert, and (2) data of validation result of the audience. The data validation of learning expert is shown at Table 1.

The results of validation I showed that from eight validated learning steps, there were 4 learning steps that had a score of 2 or valid, which were the steps of the orientation of geographical phenomena, identifying and formulating problems, doing fieldwork, and organizing, analyzing, and concluding the results of data analysis. While the other 4 learning steps had a score of 1 or needed revision, which were developing and selecting solutions, taking action, composing reports and communication, and reflections. Based on the first validator suggestion, it must be revised.

After the first-phase validation was completed, the revised product of development results was submitted for a secondphase validation. The second stage validation results showed that from eight learning steps that had been validated in the first stage, there were six learning steps that had a score of 2 or valid, which were the orientation of geographical phenomena, identifying and formulating problems, doing fieldwork, organizing, analyzing, and concluding the results of data analysis, and developing and selecting solutions, and composing reports and communication. Meanwhile the other two steps had a score of 1 or revision, namely taking action and reflection. According to the second validator, the revision of the development product on the learning step needed to be revised. The results of product trial after product validation of geography learning model development to strengthen the character of learners are shown at Table 2.

From the eighth learning steps, the highest score was $97 \%$, and the lowest score was $88.20 \%$. The highest score was the step of doing safety moment and observation, and the lowest scores were the delivery of learning objectives, reflection and following-up. The test result scores indicated that the overall scores of the test results were above the predetermined criteria. This case means that the learning steps could be accepted by the learners and applied by the educators in the learning process. The data analysis of validation result I and validation result II is listed in the Table 3 and Table 4.
TABLE I. SCORE OF LEARNING EXPERT VALIDATOR

\begin{tabular}{|l|l|l|l|l|l|}
\hline \multirow{2}{*}{ No } & \multicolumn{1}{|c|}{$\begin{array}{c}\text { Aspect that be } \\
\text { Evaluated }\end{array}$} & Score & Regard & Score & Regard \\
\cline { 3 - 6 } & $\begin{array}{l}\text { Orientation of } \\
\text { geographical } \\
\text { phenomena }\end{array}$ & 2 & Valid & 2 & Valid \\
\hline 2 & $\begin{array}{l}\text { Identifying and } \\
\text { formulating problems }\end{array}$ & 2 & Valid & 2 & Valid \\
\hline 3 & Doing fieldwork and I the & 2 & Valid & 2 & Valid \\
\hline 4 & $\begin{array}{l}\text { Organizing, analyzing, } \\
\text { and concluding } \\
\text { results of data analysis }\end{array}$ & 2 & Valid & 2 & Valid \\
\hline 5 & $\begin{array}{l}\text { Developing } \\
\text { selecting solutions }\end{array}$ & 1 & Revision & 2 & Valid \\
\hline 6 & Taking action & 1 & Revision & 1 & Revision \\
\hline 7 & $\begin{array}{l}\text { Composing reports and } \\
\text { communication }\end{array}$ & 1 & Revision & 2 & Valid \\
\hline 8 & Reflection & 1 & Revision & 1 & Revision \\
\hline
\end{tabular}

\section{TABLE II. SCORE OF TRIAL}

\begin{tabular}{|c|c|c|c|c|c|}
\hline \multirow[t]{2}{*}{ No } & \multirow[t]{2}{*}{ Items that are Evaluated } & \multicolumn{2}{|c|}{$\begin{array}{c}\text { Score and } \\
\text { Frequency }\end{array}$} & \multirow[t]{2}{*}{ Percentage } & \multirow[t]{2}{*}{ Regard } \\
\hline & & 1 & 2 & & \\
\hline 1 & $\begin{array}{l}\text { Orientation of geographical } \\
\text { phenomena }\end{array}$ & 2 & 32 & 94,10 & Valid \\
\hline 2 & $\begin{array}{ll}\text { Identifying } & \text { and } \\
\text { formulating problems }\end{array}$ & 3 & 31 & 91,17 & Valid \\
\hline 3 & Doing fieldwork & 1 & 33 & 97,00 & Valid \\
\hline 4 & $\begin{array}{l}\text { Organizing, analyzing, and } \\
\text { concluding the results of } \\
\text { data analysis }\end{array}$ & 2 & 32 & 94,10 & Valid \\
\hline 5 & $\begin{array}{l}\text { Developing and selecting } \\
\text { solutions }\end{array}$ & 3 & 31 & 91,17 & Valid \\
\hline 6 & Taking action & 2 & 32 & 94,10 & Valid \\
\hline 7 & $\begin{array}{l}\text { Composing reports and } \\
\text { communication }\end{array}$ & 2 & 32 & 94,10 & Valid \\
\hline 8 & Reflection & 4 & 30 & 88,20 & Valid \\
\hline
\end{tabular}

TABLE III. FOLLOWING UP OF VALIDATION RESULT

\begin{tabular}{|c|c|c|c|c|c|c|c|}
\hline \multirow[b]{2}{*}{ No } & \multirow[b]{2}{*}{$\begin{array}{l}\text { Score } \\
\text { Item }\end{array}$} & \multicolumn{3}{|c|}{ Validation I } & \multicolumn{3}{|c|}{ Validation II } \\
\hline & & $\begin{array}{l}\text { Sum } \\
\text { Item }\end{array}$ & $\begin{array}{c}\text { Last } \\
\text { Score } \\
(\%)\end{array}$ & $\begin{array}{c}\text { Following } \\
\text { Up }\end{array}$ & $\begin{array}{l}\text { Number } \\
\text { of Items }\end{array}$ & $\begin{array}{c}\text { Last } \\
\text { Score } \\
(\%)\end{array}$ & $\begin{array}{c}\text { Following } \\
\text { Up }\end{array}$ \\
\hline 1 & $\begin{array}{l}\text { Score } \\
1\end{array}$ & 4 & 75 & $\begin{array}{l}\text { Major } \\
\text { Revision }\end{array}$ & 6 & & $\begin{array}{l}\text { Minor } \\
\text { Revision }\end{array}$ \\
\hline 2 & $\begin{array}{l}\text { Score } \\
2\end{array}$ & 4 & & & 2 & 87,5 & \\
\hline
\end{tabular}

TABLE IV. FOLLOWING-UP EACH DATA ITEM

\begin{tabular}{|l|l|l|l|l|l|}
\hline No & Criteria & $\boldsymbol{\%}$ & $\begin{array}{c}\text { Number } \\
\text { of Item }\end{array}$ & $\boldsymbol{\%}$ & Following-Up \\
\hline 1 & Valid & $>76$ & 8 & 100 & be used \\
\hline 2 & Not Valid & $<76$ & 0 & 0 & - \\
\hline
\end{tabular}


Based on the opinion of the validator I, the invalid learning step needed to be revised. The revisions were executed, regarding (1) elaboration. In elaboration activities, it wass suggested that the learners' knowledge could be expanded through various sources, such as reading textbooks, print and electronic media, and discussing with experts. (2) Discussions and conclusions. For discussion activities and conclusions, it was recommended that this step could ensure that each learner contributed an opinion or an idea. For conclusions, it may be suggested that concrete items could be acted upon in action. (3) Taking action. The recommended actions are creating an operational planning as a reference in the field. (4) Reflection and following-up. For reflection and following-up, it was suggested to highlight the learners' feelings after given a series of lessons.

Based on validator II input, the invalid learning step needed to be revised. The revisions were (1) discussions and conclusions. Discussion activities and conclusions were suggested that the issues discussed refer to the real problems of spatial dimension. (2) Reflection and following-up. For reflection, an instrument was created that made it easy for learners to express their feelings, and the data could be used for educators in helping to formulate the following-up.

The data analysis of the trial results showed a score of 254 from 256 or $87.75 \%$. Referring to the criteria of the prevalence of $76 \%$, then the test result score wass greater than the criteria set or $87.75 \%>76 \%$. Based on the criteria of the validity, the development of Geography Learning Model for Character Reinforcement is feasible to use and does not need to be retested.

The result of this development research is the development of geography learning model to strengthen student's character, which consists of eight steps, i.e orientation of geographical phenomena, identifying and formulating problems, doing fieldwork, organizing, analyzing, and concluding the results of data analysis, developing and selecting solutions, taking action, composing reports and communication, and reflection. These eight development steps have been validated and tested and the results showed that the development product is feasible to use in geography learning in schools. The feasibility of the learning model is based on a number of advantages. There are eight advantages of this model, namely (1) starting from the contextual reality, (2) independently activating thinking and working. (3) Developing critical thinking, (4) developing knowledge of sharing habits/experiences, (5) building a reflective attitude for continuous improvement, (6) getting used to work in teams.

The six advantages of the model appear because the model is supported by four approaches. The four approaches are holistic learning, contextual learning, active learning, and cooperative learning approach. The four approaches interact with each other to strengthen the model. First, GLSC applies the principles of holistic learning. The principles of holistic learning are knowing the good thing, feeling the good thing, and acting the good thing. Knowing the good thing in the form of knowledge transfer is good. After knowing the good thing, someone must cultivate the feeling and love the good thing, that is how to feel and love the virtue to become a motivator that can stimulate people always want to do something good so grow the awareness to do behavior of virtue, because of her love of behavior of virtue. Once accustomed to do the good thing, then act the good one in the form of real actions to be familiarized in daily activities

Second, GLSC applies the principles of contextual learning. The principles of contextual learning are to help students link the content of the subject matter to the real-world situation, motivate students to relate the knowledge gained and its application in the lives of students as family members, as citizens and as workers later. The principles of contextual learning applied in GLSC include (1) involving students to observe/conserve the phenomenon of reality of moral decline, such as physical and psychological violence, messaging using mobile phone while motorcycles ignoring the safety, pornography among adolescents, (2) motivating students to do question and answer in communication and confirmation, (3) building and expanding knowledge by reading, discussion, and presentation, (4) engaging students in discussions to build learning communities, (5) making an authentic assessment [11].

Third, GLSC applies the concept of active learning. The concepts of active learning used in this model are (1) encouraging students to work to discover, process and apply information, (2) teaching students to work together, work in teams, divide work, and build a common view [12]. The application of active learning in PGPK, among others: (1) encouraging students to observe to collect decadence moral information, analyze decadence of moral information obtained, and apply them individually or in groups. (2) Involving students to work in teams in reviewing the information of moral decline, (3) building new perspectives through discussion/discussion of moral issues

Fourth, GLSC applies the principles of cooperative learning. The principles of cooperative learning are (1) positive interdependence, (2) individual responsibility tags, (3) face to face, (4) communication among members, (5) group process evaluation [13]-[15]. The principles of cooperative learning applied in PBS, among others (1) creating interaction among students to complete joint tasks, (2) strengthening individual responsibility in knowledge elaboration activities, (3) facilitating students face-to-face in groups and classes to examine issues of moral degradation, 4) involving students to communicate the results of their embedding in communication and confirmation activities. Therefore, GLSC is a new learning model in geography learning to strengthen the learner's character developed based on the contextual learning, active learning, cooperative learning, and holistic learning.

\section{CONCLUSION}

The result of the product development was in the form of Geography Learning Model to Strengthen Character. The learning model consists of eight learning steps, namely orientation of geographical phenomena, identifying and formulating problems, doing fieldwork, organizing, analyzing, and concluding the results of data analysis, developing and selecting solutions, taking action, composing reports and communication, and reflection. 
The results of the final validation of the instructional experts showed higher acquisition scores than the defined criteria, i.e $87.5 \%>76 \%$. The results of these trials presented higher acquisition scores than criteria scores, $87.75 \%>76 \%$. Hence, all the learning steps in the geography learning model to strengthen student's characters meet the criteria of validity so that it can be used in geography learning at school.

\section{REFERENCES}

[1] F. Mangunsong, "Sambutan ketua APPI Pusat," 2010.

[2] M. Nuh, "Pentingnya Pendidikan Karakter dalam Memecahkan Permasalahan kemorosotan Moral Bangsa," TV One, Indonesia, 2011.

[3] Suyanto, "Pendidikan karakter untuk anak bangsa kini dan ke depan," in Seminar Pendidikan, 2008.

[4] A. Sudrajat, "Pendidikan Karakter di SMP," Artikel Pendidikan, 2010 .

[Online].Available:https://akhmadsudrajat.wordpress.com/2010/08/ 20/pendidikan-karakter-di-smp/. [Accessed: 16-Jun-2017].

[5] Suyadi, Strategi Pemebelajaran Pendidikan Karakter. Bandung: Remaja Rosdakarya, 2013.

[6] Menteri Pendidikan Nasional, Lampiran Peraturan Menteri Pendidikan Nasional Nomor 22 tahun 2006. Indonesia, 2006, p. 43.
[7] Jawa Pos, "Pendidikan Karakter semakin tercerabut," p. 42, 14-Feb2011.

[8] MGMP Geografi Kab Pasuruan, "Pembelajaran Geografi Terkini," 2012.

[9] Purwanto, "Pidato Pengukuhan Guru Besar," 2010.

[10] M. D. Gall, B. W.R., and J. P. Gall, Educational Research: an intruduction, 6th ed. White Plains, NY, England: Longman Publishing, 1996.

[11] S. J. Sears, Introduction to contextual teaching and learning. Bloomington, Indiana: Phi Delta Kappa Educational Foundation, 2003.

[12] D. Bell and J. Kahrhoff, Active Learning Handbook: Institute for Excellence in Teaching and Learning. St. Louis, Missouri: Faculty Development Center, Webster University, 2006.

[13] A. Lie, Cooperative Learning. Jakarta: Grasindo, 2002.

[14] R. E. Slavin, Cooperative Learning Theory, Research and Practice, 2nd editio. Pearson, 1994.

[15] B. E. Soetjipto, "Model-Model Pembelajaran Kooperatif Versi Kagan. Makalah," in Seminar Nasional Himpunan Sarjana Pendidikan Ilmu-Ilmu Sosial Indonesia (HISPISI), 2011. 